\title{
Relationship among Same House Contact with Tuberculosis Patients with Associated Risk Factors in East Aceh Regency
}

\author{
Sasilia $^{1}$, Z.Amir ${ }^{2}$, T.A.Nasution ${ }^{3}$, D.N.Santi ${ }^{4}$ \\ ${ }^{1}$ Health Services East Aceh Regency, Indonesia \\ sasiliakhemaleyahoo.co.id \\ ${ }^{2,3}$ Faculty of Medicine University of Sumatera Utara, Indonesia \\ zainamir54@gmail.com \\ tettyeusu.ac.id \\ ${ }^{4}$ Faculty of Public Health University of Sumatera Utara, Indonesia \\ devi@usu.ac.id
}

\begin{abstract}
Tuberculosis (TB) is a public health problem with global challenges. Several risk factors play role in the incidence of TB transmission in same house contact TB patient. In East Aceh Regency, pulmonary TB cases increased from 210 (36.4\%) cases in 2010 to $236(40.9 \%)$ cases in 2011.

Aim of the study is to identify the correlation between some risk factors with TB transmission in same house contact TB patient in East Aceh Regency.

The study method is cross sectional. There were 140 respondents consist of family members who living in same house with TB patient. Data were obtained from interviews, examination of sputum, examination of lung radiology and Mantoux tests.

The results showed 9 persons $(6.4 \%)$ with AFB positive, 7 persons $(5.0 \%)$ with TB positive from radiology and 13 persons $(\mathbf{9 . 3 \%})$ with Mantoux tests positive. Out of 18 respondents $<15$ years old, only 1 person who received BCG vaccination.

The analysis found there are correlation between age $<15$ years old $(p=0.0001)$, poor knowledge $(p=0.0001)$ and poor nutritional status $(p=0.002)$ with transmission of TB. Some respondents $(<15$ years old) slept in same room had very closed contact with TB patients. Poor knowledge about TB also affects the transmission. While the nutritional status most probably due to low capabilities of purchasing basic food. Overall transmission of TB occurs in 29 persons $(12.9 \%)$ and associated risk factors are age $<15$ years, old, poor knowledge and poor nutritional status.
\end{abstract}

Keywords — Risk factors, same house, TB patient, transmission of TB

\section{INTRODUCTION}

Tuberculosis (TB) is an infectious disease caused by Mycobacterium tuberculosis. TB is still a health problem in the world, ranks as second leading causes of death from infectious diseases after Human Immunodeficiency Virus (HIV) [1].

Indonesia now on fifth ranked among countries with the world's highest TB burden. It was estimated the prevalence of TB cases is 660.000 and estimation of TB incidence up to 430.000 new cases per year [2]. TB is still a public health problem with global challenges. Indonesia is the first country among the countries with high TB burden in the Southeast Asia region which managed to reach the global targets for TB in 2006 , i.e. $70 \%$ of the discovery of new cases of TB smear positive and $85 \%$ cured. Currently Indonesia's ranked has deprived from fifth into third place among countries with the highest TB burden in the world. Even so, a variety of new challenges were need to be concern i.e. TB with Human Immunodeficiency Virus (HIV), Multi Drug Resistant TB (MDR-TB), TB in children and other vulnerable communities [3].

Late diagnosis and treatment will affect the population of surrounding patients, where the likelihood of a person infected in accordance with the TB transmission is generally via "droplets nucleus". The International Standard for TB Care (ISTC) stressed to all health care providers for TB patients should ensure that all people who had close contacts with infectious TB patients should be evaluated and received appropriate international recommendations. Investigation determined primarily based on the contacts: 1) who suffering from undiagnosed TB; 2) who had high risk to be infected with TB; 3) who had risk of suffering from severe TB; 4) who had high-risk infected by TB patients. The highest priority for contacts evaluation are: 1) people with most likely had TB symptoms; 2) under 5 year old boy; 3 ) suspected contacts which is 
suffering from immunocompromised, particularly HIV infection; 4) contact with MDR/Extensively Drug Resistant (XDR) TB patients. The prevalence of tuberculosis infection ascending in children at home who are in contact with the adult pulmonary TB patients, thus these are more likely in the population, and this was significantly greater on contact with TB patients with AFB (Acid-Fast Bacteria) positive. While other closed contacts have lower probability Error! Reference source not found..

Risk factors which related to the incidence of pulmonary TB are grouped into 2 groups, namely population risk factors (gender, age, nutritional status, socio-economic conditions) and environmental risk factors (density, floor, lighting, ventilation, humidity and altitude) [5]. Previous study found that the air humidity in bedroom ( $p=$ $0.002)$, ventilation $(p=0.002)$, history of contact transmission $(p=0.001)$, nutritional status $(p=$ $0,015)$, history of smoking habit $(p=0,019)$ and level of knowledge $(p=0.001)$ are the variable factors that indicate relationship of TB incidence in adult [6]. In other study, it was found that eventhough family members were living in same house with TB patient with AFB positive, but it wasn't so easily to be infected. Especially in adults, as much as 78 people who had been examined were found AFB negative, however in children $<5$ years old showed a Tuberculin test result with more than $10 \mathrm{~mm}$ diameter [4].

Pulmonary $\mathrm{TB}$ in Aceh province still needed attention because of TB prevalence in Aceh was $1.45 \%$ while the national TB prevalence was $0.99 \%$. The incident went down from 130/100,000 population into 104/100,000 population in 2008. Case Detection Rate (CDR) in the last five years is in range of $35.5 \%$ in 2007 and $51.9 \%$ in 2006. This achievement is far below the national target of at least 70\% [7].

Pulmonary TB cases in East Aceh Regency, based on the Profile of East Aceh Health Office in 2011 showed an increase of $210(36,4 \%)$ cases of pulmonary TB with AFB positive in 2010 to 236 $(40,9 \%)$ cases of pulmonary TB with AFB positive in 2011. The quarterly data reported the discovery of a new case with AFB positive on 1st quarter found 60 cases of pulmonary TB with AFB positive , 2nd quarter found 63 cases of pulmonary TB with AFB positive and 3rd quarter found 51 cases of pulmonary
TB with AFB positive among population of 360,465 inhabitants. The increased of pulmonary TB cases are influenced by a variety of factors such as the community behaviour, families, survivors, environment and home conditions [8].

Prevention activities to break the chain of transmission are by knowing the factors, especially in the sphere nearest the patient's family [9]

Based on the previous data there were still a problem in low number of CDR in East Aceh Regency. This is the reason why the study being held so that researcher could get more information to identify new cases which is related to risk factors on same house contact with TB patients

\section{THEORY}

According to $\mathrm{WHO}, \mathrm{TB}$ is a disease which most commonly affects the lungs. The disease is transmitted from person to person through fluid from the throat and lungs of a person with active respiratory disease. According to Perhimpunan Dokter Paru Indonesia (PDPI), classification of pulmonary TB were:

1) Based on the AFB staining examination results from the patient sputum

2) Based on the patient's type [10].

An American Association Lungs (2013) states that when the people with pulmonary or laryngeal TB cough,laugh, sneeze, sing, or talk, then the germs that cause TB risk will be spread into the air. If other people breathe in these germs, then there is a chance they will be exposed to tuberculosis infection. In general, it takes repeated contact to the occurrence of the infection process and supported with a person's immune condition.

Medical treatment in prevention of pulmonary TB according to Zain (2001) in Muttaqin (2009) were:

1) Examination of close contact people to the TB patients.

2) Performed tuberculin tests. Lung radiology, repeated at 6 and 12 months. Mass Chest X ray examination of certain group population

3) BCG Vaccination

4) Chemoprofilaxis using INH $5 \mathrm{mg} / \mathrm{kg}$ body weight for 612 months. The goal is to reduce and destroy number of bacteria.

5) Communication, information and education (KIE) about TB to society level and hospital level [11] 


\section{METHODS}

The study method is cross sectional. There were 140 respondents consist of family members living in same house contact with TB patient. Data were obtained from interviews, examination of sputum, examination of lung radiology and Mantoux tests. This is the first study to find out whether age, knowledge and nutritional status have correlation with TB transmission in the family living in same house with TB patients in East Aceh Regency.

\section{RESULTS AND DISCUSSION}

TABLE I

CHARACTERISTICS OF RESPONDENTS BASED ON AGE, GENDER, KNOWLEDGE, AND NUTRITIONAL STATUS

\begin{tabular}{|l|l|c|c|}
\hline No. & Characteristics of Respondents & $\mathbf{n}$ & $\mathbf{\%}$ \\
\hline $\mathbf{1 .}$ & Age & & \\
\hline & $<15$ years & 18 & 12,9 \\
\hline & $15-55$ years & 89 & 63,6 \\
\hline & $\geq 56$ years & 33 & 23,6 \\
\hline & Total & 140 & 100 \\
\hline $\mathbf{2 .}$ & Knowledge & & \\
\hline & Poor & 90 & 64,3 \\
\hline & Good & 37 & 26,4 \\
\hline & Unidentified & 13 & 9,3 \\
\hline & Total & 140 & 100 \\
\hline 3. & Nutritional Status & & \\
\hline & Poor & 41 & 29,3 \\
\hline & Normal & 89 & 63,6 \\
\hline & Overweight & 10 & 7,1 \\
\hline & Total & 140 & 100 \\
\hline
\end{tabular}

From age characteristics, the highest proportion of respondents is in group 15-49 years, as many as 89 people $(63,6 \%)$. Based on level of knowledge it is showed the highest proportion is poor knowledge about pulmonary TB that is as many as 90 people $(64.3 \%)$ with an assessment score $\leqslant 50 \%$. Based on nutritional status, it is showed that the proportion of highest nutritional status is in normal condition as many as 89 people $(63.6 \%)$.

TABLE II

RESPONDENT EXAMINATION RESULTS

\begin{tabular}{|l|l|c|c|}
\hline No. & \multicolumn{1}{|c|}{ Examination Results } & $\mathbf{n}$ & $\mathbf{\%}$ \\
\hline 1. & AFB positive & 9 & 6,4 \\
\hline 2. & AFB negative & 104 & 74,3 \\
\hline 3. & AFB negative radiology positive & 7 & 5,0 \\
\hline 4. & AFB negative radiology negative & 2 & 1,4 \\
\hline 5. & Mantoux test positive & 13 & 9,3 \\
\hline 6. & Mantoux test negative & 5 & 3,6 \\
\hline \multicolumn{2}{|l|}{ Total } & 140 & 100 \\
\hline
\end{tabular}

Based on examination results of 140 respondents, there were $9(6.4 \%)$ respondents of $\mathrm{TB}$ with $\mathrm{AFB}$ positive, $7(5.0 \%)$ respondents of $\mathrm{TB}$ with $\mathrm{AFB}$ negative but positive from lung radiology and 13 $(9.3 \%)$ respondents with positive Mantoux tests.

From Table 2, TB transmission in same house contact occured only in $29(12.9 \%)$ respondents. However, it does not occured in 111 (79.3\%) respondents.

TABLE III

RELATIONSHIP OF AGE, KNOWLEDGE, AND NUTRITIONAL STATUS WITH TB TRANSMISSION IN SAME HOUSE

\begin{tabular}{|c|c|c|c|c|c|c|c|c|}
\hline \multirow[t]{3}{*}{ No } & \multirow{3}{*}{$\begin{array}{c}\text { Characteristics } \\
\text { Of } \\
\text { Respondents }\end{array}$} & \multicolumn{6}{|c|}{ Penularan TB } & \multirow[t]{3}{*}{$\mathbf{p}^{\mathbf{a}}$} \\
\hline & & \multicolumn{2}{|c|}{ Ada } & \multicolumn{2}{|c|}{ Tidak } & \multicolumn{2}{|c|}{ Total } & \\
\hline & & $\mathrm{n}$ & $\%$ & $\mathrm{n}$ & $\%$ & $\mathrm{n}$ & $\%$ & \\
\hline \multirow[t]{4}{*}{1.} & Age & & & & & & & \\
\hline & $<15$ years & 13 & 44,8 & 5 & 4,5 & 18 & 12,9 & \multirow{3}{*}{$\stackrel{\overline{8}}{\hat{\sigma}}$} \\
\hline & $15-55$ years & 10 & 34,5 & 79 & 71,2 & 89 & 63,6 & \\
\hline & $\geq 56$ years & 6 & 20,7 & 27 & 24,3 & 33 & 23,6 & \\
\hline \multirow[t]{4}{*}{2.} & Knowledge & & & & & & & \\
\hline & Poor & 19 & 65,5 & 71 & 64,0 & 90 & 64,3 & \multirow{3}{*}{$\begin{array}{l}\overline{8} \\
\stackrel{8}{\sigma}\end{array}$} \\
\hline & Good & 1 & 3,4 & 36 & 32,4 & 37 & 26,4 & \\
\hline & Unidentified & 9 & 31,0 & 4 & 3,6 & 13 & 9,3 & \\
\hline \multirow[t]{4}{*}{3.} & $\begin{array}{l}\text { Nutritional } \\
\text { Status }\end{array}$ & & & & & & & \\
\hline & Poor & 16 & 55,2 & 25 & 22,5 & 41 & 29,3 & \multirow{3}{*}{ 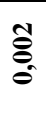 } \\
\hline & Normal & 13 & 44,8 & 76 & 68,5 & 89 & 63,6 & \\
\hline & Overweight & 0 & 0 & 10 & 9,0 & 10 & 7,1 & \\
\hline
\end{tabular}

From age characteristics, the Chi square test result showed that there is a significant relationship between age $<15$ years with pulmonary TB transmission ( $p=0.0001)$. Same result with the relationship between poor knowledge and pulmonary TB transmission $(p=0.0001)$. As a matter of fact, nutritional status also showed a significant relationship between poor nutritional status with pulmonary TB transmission $(p=0.002)$

Significant correlation between age with transmission of TB in this study in line with previous study by Dotulong (2015) which stated that there is a significant relationship between Pulmonary TB disease occurrence with age at villages in sub district Wori Wori [12].

The reason from respondents aged $<15$-year with TB transmission most likely due to sleeping in same room which has closed contact with the TB patients(data not shown in this study). 
The risk of TB transmission due to a closed room can overcome with the habit of opening the window every morning. This activity is one of the main prevention of pulmonary TB transmission. The purpose is to let sunlight enter the rooms in the house. Additionally the windows can function as air exchange ventilation [13].

According to study from Widoyono (2008) in Fitriani (2013), a patient with AFB positive has higher potentially transmitting TB disease. Every patient with AFB positive most likely will transmit 10-15 other people, so the possibility of each contact to be infected is $17 \%$ [14].

The results of other studies reported that the nearest contact (e.g. family same house) will be two times more risky than regular contact (not living in the same house).

Transmission of TB could be caused by poor knowledge about TB and mode of TB transmission in living same house with TB patient. Knowledge is influenced by level of education as one of influenced factor that play a role in affecting the decisions for someone to behave healthy [15]

The poor nutritional status will give 2.101 times more likely to suffer from disease TB compared with normal nutritional status [16]. The link between TB transmission with poor nutritional status is most likely related with the ability of society that is still low to buy the staple food.

\section{CONCLUSIONS}

There are relationship among same house contact TB patients with age, knowledge and nutritional status factors in East Aceh Regency

Based on examination results of 140 respondents, there were $9(6.4 \%)$ respondents of $\mathrm{TB}$ with $\mathrm{AFB}$ positive, $7(5.0 \%)$ respondents of $\mathrm{TB}$ with $\mathrm{AFB}$ negative but positive from lung radiology and 13 (9.3\%) respondents with positive Mantoux tests.

Out of 18 respondents (<15 years old) only 1 person who received $B C G$ vaccination. The analysis found there are relationships between age $<15$ years $(p=0.0001)$, poor knowledge $(p=0.0001)$ and poor nutritional status $(p=0.002)$ with TB transmission in same house contact with $\mathrm{TB}$ patients. Nevertheless, TB transmission occured only in 29 $(12.9 \%)$ respondents. It does not occured in 111 $(79.3 \%)$ respondents.

\section{SUGGESTIONS}

The study recommended to East Aceh Regency Health Services to do more health promotion in order to minimize the risk of occurrence of pulmonary TB and also to improve TB knowledge through health education.

For poor nutritional status and poor knowledge, the health workers have to do home visits and nutritious feeding programme continuously.

To prevent the transmission in same house contact, health workers have to educate about personal hygiene for TB patients as well as for other family members. Along with this also nutritional status need to be improved both for TB patient and family members.

Last but not least health workers periodically remind them to get more information about TB in order to prevent the disease transmit to other healthy family member in same house.

\section{ACKNOWLEDGMENT}

The Head Of UPT. Ministry of Health in the East Aceh District region and particularly the Head of UPT. The Ministry of Health in Peureulak which gave permission to do the study in the region.

\section{REFERENCE}

[1] “Global Tuberculosis Report 2013," World Health Government (WHO)

[2] "Reports 2010,” World Health Government (WHO).

[3] "Rencana Aksi Nasional TB-HIV Pengendalian Tuberkulosis 2011 2014," Kementerian Kesehatan RI Direktorat Jenderal Pengendalian Penyakit dan Penyehatan lingkungan, Jakarta.

[4] A. K. Putra, "Kejadian Tuberkulosis Pada Anggota Keluarga Yang Tinggal Serumah dengan Penderita TB Paru BTA Positif," Thesis, Fakultas Kedokteran USU, Medan, 2010.

[5] W. Rakhmawati, S. Fatimah, dan I. Nurhidayah, "Hubungan Status Gizi, Imunisasi \& Riwayat Kontak dengan Kejadian Tuberkulosis pada Anak di Wilayah kerja Puskesmas Ciawi Kabupaten Tasikmalaya," Thesis, FIK Universitas Padjadjaran, Bandung, 2008.

[6] P. Rusnoto, Rahmatullah, dan A. Udiono, "Faktor-Faktor yang Berhubungan dengan Kejadian TB Paru pada Usia Dewasa (Studi Kasus di Balai Pencegahan dan Pengobatan Penyakit Paru Pati)," Thesis, Fakultas Kedokteran UNDIP, Semarang, 2006.

[7] "Rencana Strategis Pembangunan Kesehatan Aceh 2011-2015," Dinas Kesehatan Pemerintah Aceh, Banda Aceh.

[8] "Profil Kesehatan Kabupaten Aceh Timur Tahun 2011." Dinas Kesehatan Kabupaten Aceh Timur, Aceh Timur.

[9] L. Saraswati, P. Ginandjar, W. Andriyani. Household Contact Of Pulmonary Tuberculosis In Wonogiri District, Central Java Province, Indonesia. Available: http://www.academia.edu/download/43171667/edited_article_Househo ld_contact_of_pulmonary_TB_in_wonogiri_district_by_Lintang_FPH_ DU_Indonesia.pdf

[10] "Pedoman Diagnosis dan Penatalaksanaan Tuberkulosis di Indonesia 2006.," Perhimpunan Dokter Paru Indonesia, Jakarta.

[11] A. Muttaqin, Asuhan Keperawatan Klien dengan Gangguan Sistem Pernapasan, Jakarta : Salemba Medika, 2009

[12] J.F.J. Dotulong, M.R. Sapulete, dan G.D.Kandou, "Hubungan Faktor Risiko Umur, Jenis Kelamin dan Kepadatan Hunian dengan Kejadian 
Penyakit TB Paru Di Desa Wori Kecamatan Wori,"Kedokteran Komunitas dan Tropik, vol 3, pp. 57-65, April 2015.

[13] “3B Bukan Batuk Biasa Bisa Jadi TB Pegangan untuk Kader dan Petugas Kesehatan 2010," Kementerian Kesehatan RI., Jakarta

[14] E. Fitriani, "Faktor Risiko yang Berhubungan dengan Kejadian Tuberkulosis Paru,"Unnes Journal of Public Health, vol 2, Januari 2013.

[15] "Profil Kesehatan Indonesia 2008," Depkes RI, Jakarta.

[16] Rukmini dan U.W.Chatarina, "Faktor-Faktor yang Berpengaruh terhadapKejadian Tb Paru Dewasa Di Indonesia," Buletin Penelitian Sistem Kesehatan, vol 14, pp. 320-331, Oktober 2011. 